\title{
Effects of lignite surface mining on local communities: controversies and areas of
} negotiation

\author{
Jarosław Badera*1, Leszek Pazderski² \\ ${ }_{1}^{1}$ Department of Applied Geology, Faculty of Earth Sciences, University of Silesia, Będzińska Str. 60, 41-200 Sosnowiec, Poland \\ ${ }^{2}$ Faculty of Chemistry, Nicolaus Copernicus University in Toruń, Gagarina Str. 87-100 Toruń, Poland; Greenpeace Polska \\ Foundation, Altowa Str. 4, 02-386 Warszawa, Poland \\ E-mail address (* corresponding author): jaroslaw.badera@us.edu.pl
}

\begin{abstract}
Selecting locations for lignite mining and power generation complexes has been the subject of intense controversy. As a result, there have been many conflicts in society due to environmental and economic concerns. This paper poses the question of how lignite surface mining affects local communities. These effects may be both negative and positive and some of them are intangible. It is very difficult to balance the pros and cons objectively as it depends on the assumed objectives and criteria of the analysis. Different social and economic structures in different communities, and various additional factors, are just some of the reasons why this balance may significantly differ around a country. The authors hold opposing views on the role of lignite in the energy mix and the balance of negative and positive effects that surface mining exerts on local communities. They agree, however, that the most important elements of the societal debate on lignite mining have not yet been adequately studied or presented in public discourse. The authors propose to introduce the procedure of Social Impact Assessment to the Polish legal system. This could be effective as a means to prevent many conflicts in the energy sector and be the best way to reach a compromise.
\end{abstract}

KEY WORDS: brown coal, social impact assessment, local community, pit mine

ARTICLE HISTORY: received 17 February 2017; received in revised form 11 July 2017; accepted 17 July 2017

\section{Introduction}

With a total lignite ${ }^{1}$ output of more than 60 Mt/year during recent years, Poland is Europe's second and the world's fourth largest lignite producer. Presently, among 90 lignite deposits are documented mainly in central and southwest Poland, 8 are exploited for the purposes of 5 nearby commercial power generation plants (Fig. 1). Despite long-term extraction on a considerable scale, Poland still has vast economic resources of this fossil fuel, exceeding $23.5 \mathrm{Gt}$ which could meet a considerable percentage of its electricity demand for decades to come (currently about $1 / 3$ of Polish electricity derives from lignite).

1 according to the official Polish nomenclature called "brown coal"
However, the use of any type of coal as an energy source - and choosing locations for lignite mining and power generation complexes - has for years been the subject of intense controversy in Poland. As a result, there have been many conflicts in society due to environmental or economic concerns, involving mining and energy companies, state authorities and local authorities, ecological organisations, local communities, etc.

According to KASZTELEWICZ \& PTAK (2009), lignite is, due to the lack of other energy resources in Poland, a national staple and a strategic raw material, thus its deposits should be secured for the purposes of future exploitation, especially avoiding the construction of buildings on the surface. Thus, they suggest adopting a special law for lignite surface mining, analogous to that for road building. If so, the main way to limit $\mathrm{CO}_{2}$ emissions 
(as required by EU policy) would probably be retrofitting existing power plants, without limiting lignite extraction (WIDERA ET AL., 2016). Moreover, PIETRZYK-SOKULSKA ET AL. (2015) indicate that significant income for communes ${ }^{2}$ budgets comes from lignite extraction, and that there is a link between the common directions of land reclamation and the needs of local communities.

On the other hand, according to many opponents (global and local $\mathrm{NGOs}^{3}$, some local inhabitants, etc.), even upon maintenance of environmental quality standards, the environmental damage affects very large agricultural and forested areas, and results in economic losses for local businesses and a deterioration in people's health (see the websites of Greenpeace Poland ${ }^{4}$ and the Development YES Open Pits NO Foundation ${ }^{5}$ ). Anti-lignite views are also presented by some experts, e.g. former Polish National Chief Geologist WILCZYŃSKI (2012), who says that, taking into account the scale of environmental degradation, the national interest of Poland is to follow the path described by ENERGY ROAD MAP 2050 (2011) which describes a Europe with no fossil fuels or with only their slight contribution in the energy mix. He highlights the fact that in a democratic country launching this type of investment, without wide public debate and gaining social acceptance, is practically impossible. The problem of localization conflicts in the energy sector has also been described, on a more general level, by FRĄCZEK (2011), who suggests the necessity of searching for their causes.

This paper does not pose the fundamental question of whether the use of lignite as a fuel is justified in terms of air pollution and climate change. Instead, the authors focus on how lignite surface mining (in the form of open pits) affects local communities. These effects may be both negative and positive. It is very difficult to weigh the pros and cons objectively as it depends heavily on the assumed objectives and weights

\footnotetext{
2 There are three levels of administrative divisions in Poland: provinces (sing.: województwo in Polish) are subdivided into districts (sing.: powiat), and these are further subdivided into principal units called communes (sing.: gmina).

${ }^{3}$ Non-governmental organizations

${ }^{4} \mathrm{http}: / /$ www.greenpeace.org/poland/pl/ziemia-na-krawedzi/ dlaczego/ (2008, accessed 4.11.16); http://www.greenpeace. $\mathrm{org} /$ poland/pl/press-centre/dokumenty-i-raporty/Briefing-owydarzeniu-lancuch-ludzi-STOP-odkrywce/(2014, accessed 4.11.16); http://www.greenpeace.org/poland/pl/wydarzenia/ polska/Czerwone-swiatlo-dla-odkrywki-Oscislowo/ (2017, accessed 12.06.2017); http://www.greenpeace.org/poland/pl/ wydarzenia/polska/Odkrywka-kradnie-nam-wode-protestmieszkacow-nad-wyschnieta-Notecia / (2017, accessed 12.06.2017)

${ }^{5}$ http://rozwojtak-odkrywkinie.pl/index.php/pl/ (accessed 4.11.16)
}

assigned to individual criteria in the analysis. In effect, public opinion is greatly divided on this topic, just like the opinions of experts representing different groups of interest ${ }^{6}$.

The authors of this paper hold different views on the role of lignite in the Polish energy mix and on the balance of negative and positive impacts that pit mines exert on local communities. Their aim, however, is to highlight the most important elements of the social debate generated by lignite surface mining, elements which have not yet been adequately studied in public discourse. In our opinion, such an innovative approach is necessary to continue the discussion, without rejecting opposite views a priori.

This paper refers to specific Polish conditions and the legal system regulating the environmental and social aspects of lignite mining. However, Poland, being a European Union member since 2004, is simply a good example illustrating similar issues in various other EU member states and candidate states. This is due to the fact that during the last few years several new surface mining projects have been announced in Poland (some amounting to as much as 4 billion $\mathrm{Mg}$ of lignite $^{7}$ ), each of them resulting in fierce local controversies. Similar conflicts are also observed in other European countries (e.g. DiCKMANN, 2008). Thus, the observations and conclusions collected within this study can probably also be applied in the case of such lignite producers as Germany, the Czech Republic, Greece, Bulgaria, Serbia, etc.

\section{Negative local effects of surface mining}

Lignite surface mining has all kinds of environmental impacts as described in the Polish Environmental Protection Act of 27th April 2001 and the Act of $3^{\text {rd }}$ October 2008 on the Provision of Information on the Environment and its Protection, Public Participation in Environmental Protection and Environmental Impact Assessments, i.e. direct and indirect, secondary and accumulated, short-, mid- and long-term, permanent and temporary. They mainly involve landform transformation and land dewatering, as well as air and water pollution, noise and paraseismic phenomena, and biological transformations. They are presented in Fig. 2 in a generalised and simplified manner.

\footnotetext{
6 and similarly like the scientific views on the definition and types of environment, means of environmental protection, sustainable development and various human-environment relations (cf. Stern, 1993; Dutkowski, 1995; Hipel \& Walker, 2011; Harris, 2012; Sobczyk, 2014).

7 In the Legnica region (Dolny Śląsk province) (Malewski et al., 2008)
} 


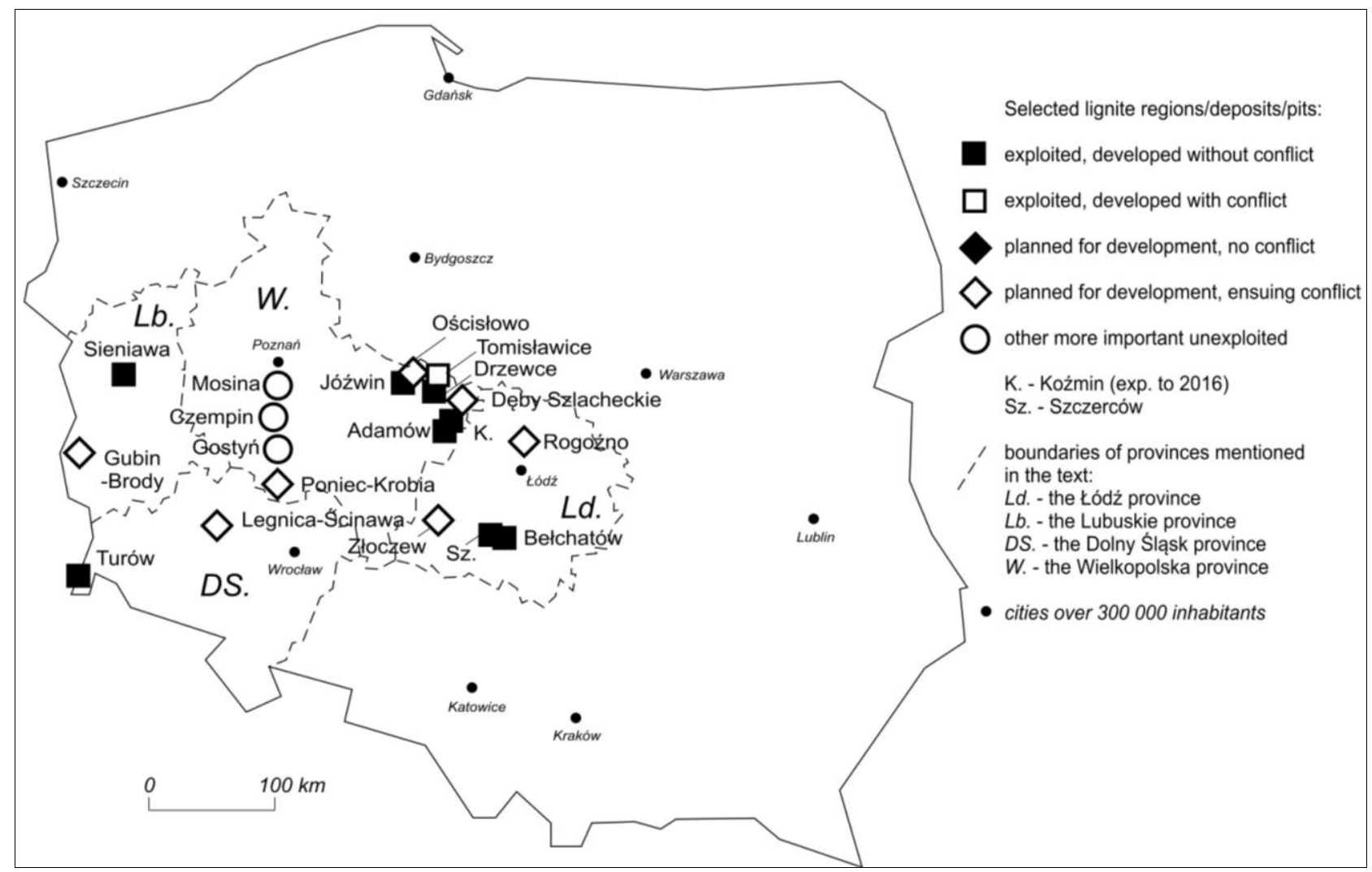

Fig. 1. Map of Polish lignite deposits against the background of the administrative division (only host provinces)

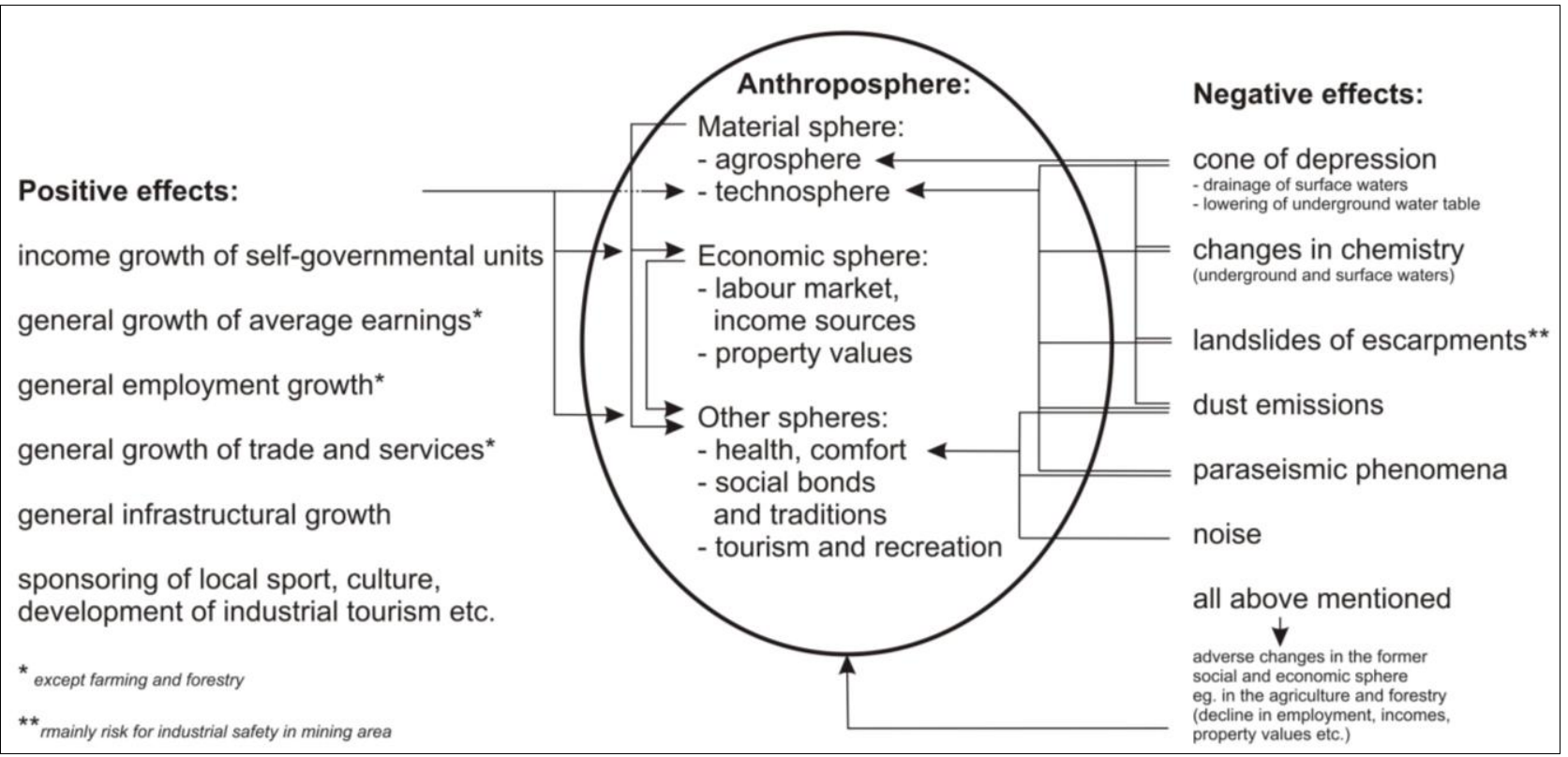

Fig. 2. Generalised model of existing and potential effects of surface lignite mining for the environment

Generally, the fact that there are negative impacts caused by surface mining on the atmo-, hydro-, pedo-, litho-, bio-, and agro- spheres as well as on part of the existing technosphere - has already been discussed in a huge number of publications and reports (e.g. DULEWSKI \& UZAROWICZ, 2004; KASZTELEWICZ \& ZAJĄCZKOWSKI, 2010; UBERMAN \& NAWORYTA, 2011). Qualitative and quantitative research on the perception of threats and anxieties among local inhabitants was carried out by BADERA
\& KoCOŃ (2014) - they showed that environmental degradation was usually understood in a complex way, without specification of the main threat. Distinct threats are well known by the public and arouse the interest of media, local authorities, NGOs and lignite enterprises who, according to the Polish Act of 9th June 2011 on Geological and Mining Law, are always liable for any damage resulting from mining plant operations. Their scale and extent is arguable and can be questioned or 
exaggerated, depending on one's viewpoint. In this paper we will skip these issues, focusing on some other, less well-known reasons why local communities oppose mining investments.

The direct threat posed to human life, caused by the lignite mining production process, mainly concerns mine employees, protected by the Labour Code and Occupational Health and Safety (OHS) regulations. Local communities are affected in a more indirect way - by polluted air and water, noise and even tremors (KASZTELEWICZ \& ZAJĄCZKOWSKI, 2010). A statistically supported diagnosis of a relationship between specific ailments suffered by inhabitants and the specific causative factor, like pit mine operation, is, however, not required during the Environmental Impact Assessment (EIA) procedure. In fact, such a diagnosis would be difficult, as it would require specialised and highly customised studies conducted on a large population, and still it would be hard to differentiate the impact of a pit mine from influences exerted by some other civilizational factors. Nevertheless, according to media reports, the issue of health remains one of the main reasons why local communities oppose new lignite projects.

Another threat that is often cited by conflicting parties is the loss to the tourist, sightseeing (both in respect to nature and culture) and recreational qualities of the region where a lignite pit is planned. The coverage of these issues, however, is not required within the EIA either. Undoubtedly, exceptionally valuable sites of natural or historical interest are often tourist attractions, but apart from the most obvious cases, these qualities are usually difficult to evaluate and disputable (cf. NAWORYTA \& BADERA, 2012). In fact, any area, even degraded to some point, carries potential in this field - hiking areas, fishing locations, some public utility buildings etc., and the extent to which these sites are used and appreciated varies in quality and intensity of transformations. Presently, almost every commune values its natural and tourist assets, even if their real potential (sightseeing and architectural attractions, network of marked trails, infrastructure of hotels and restaurants, cultural events) is relatively small. In fact, a pit mine area, especially after it has been reclaimed, may also be perceived as a tourist attraction (sightseeing spots, ski trails on former mine dumps, water reservoirs in former mine workings); on the other hand, such a landscape only has a cultural and semi-natural quality, and its value - especially the natural value - is often challenged. It must be added that a pit mine itself, with its extraordinary landscape and enormous dimensions, makes a huge impression on many people (cf. SvoBodova
ET AL., 2012) and may especially be attractive as a site of interest for fans of industrial tourism.

The concern about the tourist and recreational potential of a region raised by planned mining activities usually has clear economic motivations. Most often these anxieties are expressed by entities which profit from tourism and recreation in a given area (agrotourism farms, golf courses, etc.). Here we are getting close to a more general issue - the potential threat posed to the economic interests of individuals, companies, state-financed entities or institutions operating within or in the proximity of an area earmarked for mining activity. Particularly, these anxieties take the form of concerns over an expected drop in property values and the level or source of income. Of course, these problems concern only some individuals and corporate entities, whereas many others may benefit from activities linked to the mining industry, or, alternatively, lignite extraction would have no significant effect on their businesses.

There are yet other very subjective and intangible (so, practically not examined) aspects of the human environment such as the level of stress induced by being forced to move house, the necessity to repair mining damage (even if in both cases financial compensation, whether considered decent or not, is provided), or simply by being in the more or less bothersome neighbourhood of an extraction facility (though usually operating within permissible limits of pollution and noise emissions). This mostly applies to people who have moved out of densely urbanised and/or industrial areas to settle in the suburbs or in the countryside. Similarly, for indigenous populations, especially elders, having to move to another place may be traumatic, as it may involve breaking sentimental bonds, losing old friends or even changing their lifestyle entirely. All this provokes an understandable resistance from people (BADERA, 2010), however, an objective assessment of such nebulous influences seems to be unfeasible in practice.

\section{Positive local effects of surface mining}

From the local community's perspective, the positive effects of a new lignite pit mine in the neighbourhood are chiefly and directly associated with finances and jobs, whereas other, indirect benefits usually stem from a rise in the commune budget and the earnings of inhabitants professionally linked to the mining enterprise, companies that do business with it (especially nearby lignite-fired power plants) and other entities providing goods and services to the mine's employees (KASZTELEWICZ \& ZAJĄCZKOWSKI, 2010) 
(Fig. 2). The previously mentioned qualitative and quantitative research on the perception of benefits by local inhabitants (BADERA \& KoCOŃ, 2014) confirms that the most important things for people are the prospects related to the labour market and various indirect financial benefits.

A mine is, according to the Polish Act of $13^{\text {th }}$ November 2003 on Income of Local Self-Government Units, a source of taxes and charges, payable by a mining enterprise (all values refer to 2016):

a) $100 \%$ of property tax payable on an area of land, buildings and structures used in mining business activities $\left(0.89 \mathrm{PLN} / \mathrm{m}^{2}\right.$ for land, $22.86 \mathrm{PLN} / \mathrm{m}^{2}$ for buildings, and $2 \%$ of constructions' value) ${ }^{8}$,

b) $60 \%$ of exploitation fee for extraction of lignite (1.84 PLN/Mg) and accompanying minerals $(1 / 2$ of the normal rate, e.g. clay minerals $1.21 \mathrm{PLN} / \mathrm{m}^{3}$, peat $0.63 \mathrm{PLN} / \mathrm{m}^{3}$, sand and/or gravel $0.29 \mathrm{PLN} / \mathrm{Mg}$, lake chalk $0.125 \mathrm{PLN} / \mathrm{Mg}$ ),

c) $6.71 \%$ of $\mathrm{CIT}^{9}(19 \%)$ from the enterprise's income,

d) $37.79 \%$ of PIT 10 (18\% and $32 \%$ ) from the enterprise's employees' income.

The total revenue a commune raises from taxes is the difference between the above income and the loss of tax income caused by liquidation of some other business activities (mainly agricultural and forestry) in the mining area and their limitation or profile change (due to environmental damages). The latter tax income consists of:

a) $100 \%$ of agricultural and forestry taxes $0.013438 \mathrm{PLN} / \mathrm{m}^{2}$ and $0.004219 \mathrm{PLN} / \mathrm{m}^{2}$, respectively),

b) $100 \%$ of property tax on the area of land and residential buildings $\left(0.47 \mathrm{PLN} / \mathrm{m}^{2}\right.$ and $0.75 \mathrm{PLN} / \mathrm{m}^{2}$, respectively), as well as land, buildings and constructions used in non-mining business activities (except for agriculture and forestry, the rates are the same as those for mining business activities), c) $6.71 \%$ of CIT from the income of entities whose activity was limited or discontinued, due to the pit mine's construction (mainly agro-food companies buying food from local farms, and forest industry companies using wood from local forests),

d) $37.79 \%$ of PIT from the income of people who lost their jobs as a result of the pit mine's construction and/or moved away from the commune.

Generally, the property taxes and exploitation fees provide more income to the commune than the previous agricultural, forestry and property taxes that were paid, due to the rates' disproportion (0.89 PLN vs. 0.013 PLN or 0.004 PLN per $\mathrm{m}^{2}$ ), the

\footnotetext{
8 PLN - Polish zloty; 1 PLN = ca. $0.25 €$

${ }^{9}$ Corporate Income Tax

10 Personal Income Tax
}

increase in the area of buildings used for business activities, the increase in the structures' value, and the new exploitation fee. As this benefit is obvious and easy to calculate, it usually serves as the primary argument used to persuade a local community to give their consent for the construction of a pit mine. A key argument is often the example of the Kleszczów commune (a large Bełchatów pit mine in Łódź Province), which per capita is the richest commune in Poland (its annual budgetary income being 45,000-50,000 PLN/inhabitant, while in the capital city of Warsaw it is $7,000-8,000$ PLN/inhabitant).

There is also no doubt that pit mines operating for years in lignite-rich regions (especially those established in the communist period of 1945-1989) exert positive effects on the local labour market, mainly due to the fact that mining enterprises provide work for many employees $(31 / 12 / 2015$ : 6,300 people in pit mine companies, 4,100 in external firms providing services to pit mine companies). One must also add various people working in separate business entities engaged in work less associated with mining enterprises. It is also important that remuneration rates in pit mine companies and nearby coal-fired power plants are almost 1.8 times higher than the average remuneration in Poland $(6,925$ PLN vs. 3,900 $\mathrm{PLN} / \mathrm{month}$ in 2015). Moreover, miners, who mainly spend their money in the places where they live, generate additional demand for local goods and services, stimulating new jobs outside the mining sector. As a consequence, in the communes which have hosted lignite pit mines for years the unemployment level in 2010-2014 was usually lower than in the whole province (e.g. 5.6-7.5\% in the Kleszczów commune with the Bełchatów pit mine and power plant versus 8.1-9.7\% in Łódź Province; $5.7-7.5 \%$ in the Bogatynia commune with the Turów pit mine and power plant versus $6.6-8.3 \%$ in Dolny Śląsk Province). The same is true when one compares neighbouring districts with, and without, lignite businesses (e.g. 6.2-8.1\% in Turek district with 3 open pits ${ }^{11}$ and a power plant versus $9.3-11.2 \%$ in Łęczyca district with no coal mining, both on the border between Wielkopolska and Łódź Provinces).

\footnotetext{
${ }^{11}$ Currently, in Turek district only one lignite pit mine is in operation; the first one was closed in spring 2012, the second in summer 2016, and the last will stop excavating in 2017
} 


\section{Controversies concerning local threats from, and benefits of, surface mining}

Despite the above, there are many regions where the majority of inhabitants do not favour the idea of lignite mining, as exhibited by the results of local referenda (the Gubin and Brody communes in Lubuskie Province, Legnica region in Dolny Śląsk Province, the Babiak commune in Wielkopolska Province), where $65-90 \%$ of votes were against the investments (with turnout $>50 \%$ ). ${ }^{12}$ In some regions (the Miejska Górka-Krobia communes in Wielkopolska Province) there have even been mass protests organised by farmers and supported by local businesses.

A more positive attitude to lignite mining is held by the public in communes with pit mines that have existed for years (e.g. Kleszczów in Łódź Province). There are also communes, like Złoczew (Łódź Province), where a new lignite project does not trigger opposition on a large scale; this is usually a result of the difficult social and financial situation in a given commune, and the hopes cherished by some of the commune's inhabitants for change that will ensure economic growth and new job positions. One may also hazard a guess that the local community in the Złoczew commune welcomes the idea of lignite exploitation, both in the commune and more generally in Poland, which does not mean, however, that it is free from all concerns (BADERA \& KOCOŃ, 2014).

From a purely economic perspective, a huge complication is that a considerable portion of the taxes derived from lignite mining does not stay in communes where pit mines are located - for example, in 2006-2008 the fees and taxes paid to just these communes were only $c a$. $20 \%$ of total public charges paid by the lignite mining sector (KASZTELEWICZ, 2012). From the perspective of the state budget, consisting mainly of CIT and PIT, the place where tax is collected is irrelevant, but for the interested local self-government units - it is a matter of extreme significance. What matters to local communities is not what additional tax revenue is generated by a pit mine, but what portion supplies the budget of a given commune, district or province.

Whereas for CIT this matter is simple, the case of PIT is more challenging. The majority of people employed in mining and related enterprises (especially lignite-fired power plants) do not live in small rural communes where open-pits are located, but in nearby towns, where their taxes are

12 The results of the referenda were published in the so-called Bulletin of Public Information (BIP) directed. For example, employees of the Bełchatów, Konin and Adamów pit mines (and the related Bełchatów and Pątnów-Adamów-Konin power plants) mainly reside in the towns of Bełchatów, Konin and Turek; only in the case of the Turów pit mine and power plant do they live in the same Bogatynia commune. In contrast, a large number of workers in small agro-food and forestry companies reside in these rural communes where their companies are located, thus their taxes supply the same budget. Unfortunately, no more accurate data is available.

Due to higher earnings in the lignite mining and energy industry compared to the agro-food and forestry sectors, total PIT revenues in a given district, province or state, may rise, but from a commune's viewpoint they may not change significantly or even drop owing to the loss of jobs and/or population migration to some other communes. The situation is more beneficial for nearby middle-sized municipalities supplied by taxes paid by the miners and power plant workers inhabiting them.

This seems to happen with many of the current planned investments. Most of the future employees of the Ościsłowo and Dęby Szlacheckie open pits (Wielkopolska Province) will probably remain in the town of Konin (30 km away) and not move with their families to the villages of Wilczyn or Babiak. This may also be arguable in the case of the Złoczew investment (60 km from Bełchatów). Another case is Gubin, where the future place of residence of most miners and power plant workers will be probably the urban commune (the town of Gubin), while the pit mine is to be located in a distinct rural commune (Gubin-countryside), their budgets and administrative bodies being separate.

The influence of pit mines on the local labour market is even more complex, the picture being different for future and existing enterprises. A new pit mine in a predominantly agricultural region may have a short-term negative influence on the employment rate because the staff employed may have already been members of teams working in existing mining companies located elsewhere. Examples are the Konin and Adamów enterprises, where for many years the majority of workers have been moved from pit mines running short of resources to newly opened ones. As a consequence, for instance, in the Kramsk commune (the Drzewce pit mine) and the Wierzbinek commune (the Tomisławice pit mine), the unemployment rate (2010-14) was higher (9.3-12.7\%) than in the Babiak commune (the planned Dęby Szlacheckie pit mine, 8.8-10.8\%) and the whole of Wielkopolska Province (5.3-8.7\%). Similarly, in the Szczerców 
and Rząśnia communes (the Szczerców pit mine) it was higher (8.4-12.8\%) than in the Złoczew commune (the planned Złoczew pit mine, 8.8-9.3\%) and the parent Łódź Province (8.1-9.7\%).

A different situation may be found in the case of Gubin or Legnica (the former in Lubuskie Province, the latter in Dolny Śląsk Province), where owing to the considerable distance between the currently exploited deposits and the still large resources of the nearest Turów deposit, it is unlikely that the current miners can be transferred from the towns of Bełchatów or Bogatynia on a bigger scale; therefore, a policy of recruiting locally will probably be implemented which may also limit some of the social costs borne by the mining enterprise.

The problem is that the inhabitants of rural communes with planned open pits are often not properly educated and have no skills necessary to work in the mining industry. Lignite mining, using advanced technologies and complex machinery, may be of course an attractive future employer for young people who are yet to acquire their professional qualifications. The construction of a pit mine in the neighbourhood may provide an inspiration to choose a specific career path, and even enrol in a mining engineering college or university of technology. It is, however, hard to imagine that mining qualifications could be acquired by farmers who have worked in the farming sector for years and inhabited regions where mining activities have not been conducted before. In fact, they have no chance of getting a job in a pit mine as they simply lack the required knowledge or qualities, that would make them desirable employees for a lignite consortium. At best, they can count on being employed in various kinds of auxiliary work, often conducted not by the mining enterprise but rather by one of the companies it works with. In this last case, they will be deprived of various kinds of privileges enjoyed by miners, including social ones; the problem also lies in lower wages and less favourable forms of employment (e.g. a contract of mandate) in these types of companies.

On the other hand, a stricte mining education is not a prerequisite to work at a lignite pit mine. General and on-the-job training covering basic skills (specific for the mining industry) and OHS training, take only 30 working days even in some of the underground hard coal mines, so the most basic qualifications may be acquired in a relatively short space of time. People who hold specialist qualifications (electricians, welders etc.) are in a better situation than those in posts in administrative divisions, where mining experience is not so important.
The negative impact of open pits due to the loss of jobs in agricultural, forestry, agro-food and wood industries may be relevant for the inhabitants of a given rural commune. This is because the above sectors provide many jobs in agricultural regions, while these posts do not often require high specialist qualifications. Therefore, if those jobs are liquidated, people losing their jobs, who sometimes have no education or only a basic education, are often unable or unwilling to undergo retraining, and in consequence, are unlikely to find a new job in this commune. As they are aware of their slim chance in this field, this is one of their fundamental arguments against the construction of a pit mine in their region. Also these problems remain insufficiently examined.

What is more, in more affluent rural areas with a well-developed farming culture, the income earned by locals from farming or food processing companies may be satisfactory enough for people not to be interested in any change, including building a pit mine. For such a community, the opportunity to get jobs in a mining company may not be an attractive alternative to the jobs presently held.

Naturally, in the long term one may anticipate that the social and economic structure of a commune might undergo gradual transformation and some of the problems may disappear in time as a result of the local community's gradual adaptation to the changed labour market, the turnover of generations and to demographic changes. This may occur, however, many years from now, and generally is unacceptable for many people living in a given region "here and now".

Similarly to the case of the commune's income, any changes in the labour market, both positive and negative, triggered by the pit mine's construction, will not have an effect on those inhabitants who are forced to leave their homes and communes and often move to distant regions of the country. In fact, they may be the greatest victims of the change - even if they manage, with the use of the compensation they get, to recreate their former standard of living in new places, they may still face serious problems with finding new jobs. Some others, in turn, buy real estate in the same or neighbouring communes and still work as farmers. Another factor making the situation even more complicated is the limited supply of agricultural land in some parts of the country.

Either way, there is a need to assess to what extent the loss of jobs and CIT/PIT (regarding the portion constituting a commune's income) collected from business entities and individuals connected with the agricultural, forestry, agro-food and wood industries as well as tourism are (or will be) 
balanced by new employment positions and taxes collected from new companies and inhabitants directly or indirectly connected with the mining industry.

Demographic changes themselves are a valid but controversial issue. It may be assumed that a positive overall level of migration and a positive rate of natural increase are much-desired phenomena, serving as evidence for the developmental potential of a given administrative unit. However, in the case of lignite mining the situation varies for different regions irrespective of the time when a given investment was started.

In the case of the Kleszczów commune (with the Bełchatów pit mine developed in the seventies), the situation is excellent: in the 2002-2014 period over 1500 more people settled in the commune than left the commune, with a simultaneously high natural increase rate $(0.5-0.6 \%$, annually). This resulted in the commune's population increasing by $45 \%$. In contrast, in the same period, in the Bogatynia commune (with the Turów pit mine active since the forties), the population shrank by 1500 inhabitants (by 6\%). Furthermore, in the case of the Szczerców pit mine, located in two communes (Szczerców and Rząśnia) the trends were ambiguous - in the former the population increased by $8 \%$, while in the latter it decreased by $2 \%$.

The above data do not suffice to draw an unambiguous conclusion about the scope of lignite surface mining's impact on demographic changes in communes. They depend on many internal and external conditions, requiring a more thorough analysis.

\section{Conclusion and policy implications}

Lignite pit mines (existing and planned) involve both negative and positive impacts on the anthroposphere. Generally, when drawing up their overall contribution in terms of social and economic changes, variations in tax revenues and income earned by people should be considered, as well as changes in employment structures connected with the establishment of a mining enterprise and the accompanying companies (a lignite-fired power plant, in particular) - versus the simultaneous ceasing or limitation of the activities of farms and agricultural or forestry enterprises.

The different social and economic structures of distinct communes and the various shares of commune areas that pit mines occupy as well as an additional factor, in the form of the proximity of a middle-sized municipality, are reasons why the average income of communes hosting pit mines may significantly differ within the whole country. It is similar in the case of the dynamics of the labour market, which is different for brownfield sites (traditional mining regions) and greenfield ones (planned mining regions). All the abovementioned issues may vary depending on the scale in which they are considered - individual, communal or regional.

Unfortunately, in Poland there is no institution that closely monitors migration trends, local labour markets or changes in a commune's revenues from various taxes, caused by pit mine construction, as well as connections between these socioeconomic factors. The lack of available and detailed data, together with the processes' complexity, promotes the usage of contradictory arguments and theses in public discussion on surface mining, especially in the media. As a consequence, stereotypes (used by both advocates and opponents of lignite mining) are established and reinforced, blocking the possibility of negotiations. In contrast, an honest public discussion should be backed up by the analysis of real socio-economic benefits and losses, performed in as easy and uncomplicated a way as possible so as to allow anybody to understand it.

The idea to assess the impact on the social environment is not new. In some countries (mainly Anglo-Saxon ones), a procedure called a Social Impact Assessment (SIA), originating from the already-mentioned EIA, and usually performed within its framework, is often included in formal planning and decision making processes for development projects (including mining ones). Even if this procedure is not as commonly used as an EIA, the theory and practice it encompasses has been the subject of numerous works (VANCLAY, 2014), including those tackling the problem of raw materials (KEMP, 2010; FranKS, 2012). In Polish conditions, such analyses (e.g. MALEWSKI ET AL., 2008; NAWORYTA \& BADERA, 2012; UBERMAN \& NAWORYTA, 2012) are not conducted as part of any particular procedures. It seems that introducing this type of assessment into the legal system could work as a means of preventing many conflicts in the energy sector (cf. BARROW, 2010; FRĄCZEK, 2011).

Irrespective of their contrary views on the role of lignite in the energy mix and the impact of its combustion on climatic change, the authors of this article are unanimous in their opinion that the elements of local social conflicts described above have been insufficiently examined and presented to the public. This enables both parties to such conflicts, often turning into a propaganda war, to hold opposite opinions regarding the same topic - instead of engaging in a rational 
discussion. The authors realise that any analytical explanation of the issues in question will continue to spark controversy due to the difficulty in equally distributing benefits and losses, and owing to the high emotional temperature of lignite-related conflicts. Nevertheless, rational arguments helping to relieve tensions should be considered by both parties, as in each conflict rationalisation is the best way to reach a compromise.

\section{References}

Badera J. 2010. Social conflicts on the environmental backdrop of the development of mineral deposits in Poland. Gosp. Sur. Min., 26, 1: 105-125.

Badera J., Kocoń P. 2014. Local community opinions regarding the socio-environmental aspects of lignite surface mining: experiences from central Poland. Energy Policy, 66: 507-516.

Barrow C. 2010. How is environmental conflict addressed by SIAs? Environ. Impact Ass. Rev., 30, 5: 293-301.

Dickmann F. 2008. Reclamation conditions of opencast mining in the Rhenish Lignite-mining Region (Germany). [in:] Conf. Human Impact on the Landscape and Geomorphological Hazards, Rohr Univ Bochum, Bochum. Zeit. Geomorph., 55, Suppl., 1: 15-24.

Dulewski J., Uzarowicz R. 2004. Brown coal open pits influence on the environment. WUG: Bezpieczeństwo. Pracy Ochr. Środ. Górn, 5: 3-4.

Dutkowski M. 1995. Conflicts in the use of environmental goods. Uniw. Gdański, Rozprawy rod. i Monografie 215.

Energy Road Map 2050, 2011. Communication from the Commission of European Parliament, the Council, the European Economic and Social Committee and the Committee of the Regions. EU COM (2011) 885/2, European Committee, Brussels.

Franks D. 2012. Social Impact Assessment of Resource Projects. Mining for Development: Guide to Australian Practice. Int. Mining Dev. Centre, Perth (AUS).

Frączek P. 2011. Dealing with local conflicts in the energy sector. Polityka Energetyczna, 14, 2: 65-78.

Harris F. (ed.) 2012. Global Environmental Issues, 2nd Ed. Wiley-Blackwell.

Hipel K., Walker S. 2011. Conflict analysis in environmental management. Environmetrics, 22, 3: 279-293.
Kasztelewicz Z. 2012. Pros and cons of coal mining in Poland. Polityka Energetyczna, 15, 4: 7-27.

Kasztelewicz Z., Ptak M. 2009. Selected problems of securing brown coal deposits in Poland for opencast mining activity. Polityka Energetyczna, 12, 2/2: 263-276.

Kasztelewicz Z., Zajączkowski M. 2010. Impact of lignite mining on its surroundings. Polityka Energetyczna, 13, 2: 227-243.

Kemp D. 2010. Community Relations in the Global Mining Industry: Exploring the Internal Dimensions of Externally Orientated Work. Corporate Social Responsibility Environ. Manage., 17, 1: 1-14.

Malewski J., Blachowski J., Kaźmierczak U., Kucharska M. 2008. Środowiskowe i społeczne uwarunkowania eksploatacji złoża węgla brunatnego Legnica (Raport końcowy $\mathrm{nr} 18 \mathrm{w}$ ramach:) Scenariusze rozwoju technologicznego przemysłu wydobycia i przetwórstwa węgla brunatnego / Inst. Górn. Odkr. Poltegor-Instytut, Wrocław.

Naworyta W., Badera J. 2012. Analysis of social and economic conditions for the planned development of the Gubin lignite deposit. Polityka Energetyczna, 15, 3: 107-118.

Pietrzyk-Sokulska E., Uberman R., Kulczycka J. 2015. The impact of mining on the environment in Poland - myths and reality. Gosp. Sur. Min., 31, 1: 45-64.

Sobczyk W. 2014. Sustainable development of rural areas. Problemy Ekorozwoju, 9, 1: 119-126.

Stern P. 1993. A Second Environmental Science: HumanEnvironment Interactions. Science, 260: 1897-1899.

Svobodova K., Sklenicka P., Molnarova K., Salek M. 2012. Visual preferences for the physical attributes of mining and post-mining landscapes with respect to the sociodemographic characteristics of respondents. Ecol. Eng., 43:, 34-44.

Uberman R., Naworyta W. 2011. Analysis and forecast of mining damages caused by open cast lignite mines. Zesz. Nauk. IGSMiE PAN 81: 165-175.

Uberman R., Naworyta W. 2012. Lignite exploitation under spatial and environmental restrictions - case study: Gubin lignite deposit. Polityka Energetyczna, 15, 4: 29-41.

Vanclay F. (ed.) 2014. Developments in Social Impact Assessment. Edward Elgar Publ., Cheltenham (UK).

Widera M., Kasztelewicz Z., Ptak M. 2016. Lignite mining and electricity generation in Poland: The current state and future prospects. Energy Policy, 92: 151-157.

Wilczyński M. 2012. Węgiel brunatny paliwem bez przyszłości. Inst. na Rzecz Ekorozwoju, Warszawa. 